\title{
THE IMPACT OF PSYCHOLOGICAL BIASES ON FOREIGN DIRECT INVESTMENT (FDI): THE CASE OF TURKISH INVESTORS IN ETHIOPIA
}

\author{
PSİKOLOJİK YANILGILARIN DOĞRUDAN YABANCI YATIRIMLAR \\ ÜZERINDEKİ ETKİSI: ETIYYOPYA'DAKİ TÜRK YATIRIMCILAR
}

\author{
Abdu Seid ALI* \\ Jale SÖZER ORAN ${ }^{* *}$
}

\begin{abstract}
This paper aims to assess whether there is a behavioral bias of Turkish FDI investors in Ethiopia. Besides, it addresses the influence of firm size, investment duration, target customers and amount of investment on the behavioral variables. In order to do so, a survey was conducted on a sample of Turkish FDI investors in Ethiopia which tries to examine their cognitive psychological factors towards their investment decisions. The survey result was analyzed using factor analysis. The statistical findings confirm that some psychological anomalies such as representativeness, herding, regret aversion and mental accounting have been observed on Turkish FDI investors. The regression analysis shows that amount of investment of the firms significantly and positively affects herding, representativeness, regret aversion and mental accounting behaviors. Furthermore, duration of investment in Ethiopia affects their representativeness and mental accounting behavioral biases of investors positively.
\end{abstract}

Keywords: FDI, Behavioral bias, Turkish investors, Ethiopia, Factor analysis

JEL Classification: G40, F21

Özet

Bu çalışma Etiyopyada doğrudan yatırım yapan Türk yatırımcıların davranışsal yanılgılarının olup olmadığını araştırmak amacıyla yapılmıştır. Bunun yansıra, şirket büyüklügüu, yatırım süresi, hedef müşteriler ve yatırım tutarının davranışla ilgili değişkenler üzerindeki etkisini de bulmayı hedeflemektedir. Türk yatırımcıların yatırım kararlarında etkili olan bilişsel psikolojik faktörlerin belirlenebilmesi amacıyla bir anket yapılmış ve bulgular faktör analizi ile incelenmiştir. Araştırma sonuçları Türk yatırımcılarının temsililik, sürü davranışı,

\footnotetext{
* Senior lecturer, Wolaita Sodo University (Ethiopia), Faculty of Business and Economics, Department of Accounting and Finance, abduseid81@gmail.com, 0000-0001-5783-3546

* Professor of Finance, Marmara University, Faculty of Business Administration, Department of Business Administration (English), jaleoran@marmara.edu.tr, 0000-0001-8976-2893
} 
pişmanlıktan kaçma ve zihinsel muhasebeyle ilgili hatalarını ortaya koymuştur. Regresyon analizi şirketlerin yatırım tutarlarının bu davranış hatalarını istatistiksel olarak anlamlı ve pozitif yönde etkilediğini göstermiştir. Yatırımın süresi de temsililik ve zihinsel muhasebe hatalarını pozitif yönde etkilemektedir.

Anahtar Kelimeler: Doğrudan yabancı yatırım, Davranışsal yanılgılar, Türk yatırımcılar, Faktör analizi JEL Sınıflandırma: G40, F21

\section{Introduction}

Contrary to the traditional finance that is based on neoclassical economics which asserts on rational preferences of individuals, utility maximization of people, profit maximization of firms as well as independent decisions based on all relevant information, another body of proof has emerged challenging the above facts and argues the markets are inefficient and investors might not be rational every time (Ackert \& Deaves, 2010). Behavioral finance is a comparatively new but rapidly intensifying subject that deals with associating behavioral and cognitive psychological theory with conventional economics and finance to produce clarifications for why people make irrational financial and economic decisions (Baker \& Nofsinger, 2010). Besides, Shiller (2003) emphasized that behavioral finance turns into vigorous area of research that comprises numerous market inconsistencies which were overlooked by the theory of market efficiency. After criticizing Fama’s (1998) study, Shiller inferred that the new economic model should integrate behavioral finance in order to comprehend the market well.

Hence, cognitive psychology and the limits to arbitrage are the two major constituents of behavioral finance. Cognition deals with the way people think, understand, and learn a certain situation. In behavioral finance, cognitive psychology focused on numerous biases that come into being when people develop beliefs, and on people's choices, or on how they make decisions, based on their beliefs (Shleifer \& Summers, 1990); (Barberis \& Thaler, 2003). Psychologists believe that the human mind is restricted in its capability to concentrate and deal with all the information they receive. Likewise, they emphasize that the ultimate form of our decisions made is over and over exceedingly biased by the indicators obtained by our subconscious. Consequently, investors' financial decision making can be influenced by their cognitive and heuristics biases. In addition, Statman (2008) argued that investors' cultural background greatly affects their emotional and psychological approach which guides their investing decisions.

Unlike the traditional finance which contends collective action of traders, causes mispricing opportunities in the market to cease, limits of arbitrage being the other element of behavioral finance indicates that when mispricing arises, strategies intended to correct it can be both risky and costly, in that way it permits the mispricing to persist. There are three main possible problems faced by arbitragers when there is an absence of a fairly priced close substitute for the mispriced asset. Arbitragers encountered fundamental risk due to variations in the arrival of unexpected information that makes them incapable to successfully hedge their position. They might also be confronted by noise trader risk in which trading by unaware investors can drive the mispricing to surge before 
it adjusts. Finally, implementation costs like commissions, spreads, and market impact costs spent makes the arbitrage impossible (Ackert \& Deaves, 2010; Barberis and Thaler, 2003).

Despite the fact that most of the studies on behavioral finance focused on equity markets, some studies, though, few highlighted the influence of cognitive psychological biases on foreign direct investment in different countries. Economic situations, government policies, human and technological advantages, favorable environments and others are mentioned as motivation factors of FDI to host countries. Behavioral anomalies of individual or institutional foreign investors have been given little attention in long-term decision making process of the cross boarder capital movement. Even though there are not considerable studies on FDI vis-à-vis behavioral elements, Hosseini (2005) contends that elements of behavioral economics should be considered as part and parcel of FDI since FDI is one of the significant discipline in economics. Behavioral economics, that rejects naïve economic model of rational agents merely trying to maximize their utility, is undoubtedly capable of clarifying the decision of transnational companies making investment decisions when they experience the multifaceted and indefinite global atmosphere.

According to Eiteman et.al (2013) Swedish School of Economists, which is considered among the pioneers in the behavioral approach of FDI, fruitfully expounded not only firms' preliminary decision to invest overseas but also subsequent decisions to plough their resources somewhere else again and to alter the overall arrangement of a firm's worldwide involvement over time. The analysis of a sample of Swedish multinational companies illustrates that they preferred to invest in countries which are not that much remote in cognitive terms. Neighboring countries like Finland, Denmark, Norway, Germany, and the United Kingdom were among the most favored investment destinations for Swedish investors due to somehow identical cultural, legal, and institutional setting.

Ethiopia's recent enormous achievement in creating a center of attention in FDI in terms of joining the top five FDI flows to landlocked developing countries for the first time creates some sort of curiosity about what attracts those foreign direct investors to Ethiopia. The amount of FDI flow to Ethiopia dramatically surged following the year 2012. There are several potential factors which make Ethiopia a preferred investment destination from both developed and developing countries like the general political, trade and investment agreements with the main investor countries in addition to impressive economic growth, relative political stability, cheap unskilled labor, market attractions, investment guarantee, tax exemptions and other incentives (Getinet \& Hirut (2006); Atlaw, et.al, 2014; Amanuel (2015)).

Though the above studies emphasized the economic and political factors as the major determinants for the impressive progress of FDI in the country, it is customary to check whether behavioral factors of investors affect their FDI decision making. Therefore, this study will try to examine the behavioral biases of FDI decisions of Turkish investors in Ethiopia. Turkish investors were chosen due to their engagement in an enormous FDI flow to the country recently and the convenience of collecting primary data. Moreover, as Statman (2008) mentioned above, the cultural background of investors affects their investment and business choices. Therefore, the study didn't include investors from 
other countries since it might affect the result. The study will contribute a lot for decision makers and academics to focus on behavioral factors since the economic motives merely do not explain fully why foreign direct investors are attracted to a certain country to invest.

The remaining part of the paper outlined as follows. In the next section, empirical studies related to behavioral elements of FDI were addressed individually and in group. Then, selected cognitive biases relevant for the study were discussed. After that, data, methodology and findings of the study were presented. Finally, conclusions, recommendations and policy implications along with areas for further study were put forward.

\section{Literature review}

A number of studies have been conducted regarding the influence of behavioral anomalies on the decision making of investors in financial markets all over the world in different time spans. However, little has been covered regarding the impact of behavioral biases on the green field investments abroad. Therefore, the following part of the paper reviewed important studies made in this regard. The first few studies point out a group of behavioral factors followed by studies which focused on specific cognitive elements.

Rosenboima et.al (2008) studied experimentally the impact of behavioral biases on investors' decisions surveying MBA students with prior management and accounting experiences to evaluate tax relief and grants in FDI. They found that a rise in the risk of the anticipated cash flow broadens the nominal grant necessitated by investors with the aim of abandoning tax relief, an outcome that refutes the expected utility theory. This finding can be clarified by the 'Regret Effect' that was discussed above. Moreover, they documented investors request reimbursement for shifting tax relief into a grant. Similarly, this finding is against the expected utility theory, since the grant is assured and is assumed to progress the investors' satisfaction when a tax advantage is substituted with a grant. This outcome can be described as the 'Status Quo Bias' which asserts that people incline to stay in current circumstances to delay better options. Finally, they documented that decision makers in firms are affected by the manner the motivations are presented. At times comparable incentive choices are offered in a slightly distinct fashion, and this might result in different decisions.

Content analysis was employed from interviews conducted with Portuguese managers with investments abroad by Alves (2008) and documented that herding, anchoring, overconfidence, mental accounting and other behavior irregularities in companies' location decisions that instigate a set of factors of FDI movements and complement the neoclassical paradigm. Furthermore, the study supports the Heiner model $(1983,1985,1989)$ by elucidating whenever decision makers confronted to greater uncertainty, there is a likelihood of applying behavioral guidelines. The reason why a great amount of FDI take place more recurrently within developed countries is due to the fundamental role of uncertainty in the decision making process. 
Araujo (2009) used a database of Swedish manufacturing investments in the world from 1970 to 1998 and contends that under uncertainty, investors are biased by the location decisions made by other investors and have a tendency to pick out similar targets to locate their investments thereby confirming herding behavior. In addition, the study documented that previous location decisions affects succeeding decisions positively, even after controlling for other elements like industry particular agglomeration externalities. In the same way, the findings of Kuo and Fang (2009) support that FDI investors location decision is not rational rather it is influenced by the investors mental and behavioral phenomena as well as the familiarity and experience while they are making decisions to select their destination.

A conference paper by Levis et.al (2010) investigated herding in foreign direct investment outflows with data on FDI outflows from the OECD member countries. It verified herding related to world leaders, regional leaders, portfolio equity investors and regional investments and discovered the existence of herding behavior in these FDI outflows. Specifically, Companies have a tendency to track the investment pattern of the world and regional investment leaders. In addition, FDI investors pick out an investment site with an enormous portfolio equity investment activity after two years.

A large panel dataset of the FDI inflows and outflows of 30 OECD member countries were used in a doctoral dissertation of Vasileva (2011) to assess whether there is home country bias and herding behavior. The study confirmed that there is an inclusive "home country bias" that is proved through the choice for direct investments in countries with superior physical, institutional and cultural juxtaposition to the investor country. Moreover, FDI investors lean towards herd around a superficial world or a regional frontrunner when deciding investments in distant places and when they are not accustomed with and unable to find something in common with an FDI partner country.

Hutzschenreuter et.al (2014) employed panel data of large US firms to examine how firms familiarize their product and geographic diversification as a reaction to foreign competitors delving into their local market by assuming a behavioral perspective. They found that when the amount of import surges, the local executives diminishes their product and geographic expansion. Nevertheless, when overseas firms augment market penetration in the form of FDI instead of imports, the corporate reaction happens to be a rise in product and geographic broadening. The results imply that there is behavioral bias specifically framing that is one of the components of prospect theory in US executives of large firms.

\section{Cognitive Biases}

Traditional economic theory infers that human beings make objective decisions based on past information which enables them predict the future. However, psychological studies have documented that decision makers have enduring flaws in their competency to bring inferences depending on past data and for that reason, develop inappropriate judgement relying on their previous experience. Burton and Shah ( 2013) defined cognitive bias as "a departure in inference or judgment from 
objective analysis that leads to a distortion in perception or understanding." (p:135). In this part, selected cognitive biases significant for the study i.e. herding, overconfidence, representativeness, anchoring, availability, loss aversion, regret aversion, mental accounting were presented from theoretical perspective.

\section{I. Herding}

The basic principle of traditional finance argues that investors make well-versed and rational judgement under uncertainty. Nevertheless, this doesn't always happen due to investors' behavioral inconsistencies. One these biases are herding behavior that happens when investors have a tendency to imitate and follow the decisions of other investors. They make buying and selling decisions depending on the observation of other market players instead of their own individual information and assessment (Scharfstein \& Stein, 1990). The issue of herd behavior in financial and other markets has been covered and given enormous attention both theoretically and empirically. Conversely, little has been studied concerning the inclination of investors on following the crowd in long term investment decision like FDI. According to the theory of oligopolistic markets, rival firms may potentially mimic each other and try to grab market shares in international market. Firms in an industry tend to follow each other's location decision (Knickerbocker, 1973). Hence, the essential components of the oligopoly theory can be mingled to create 'follow the leader' investment behavior in foreign destinations (Vasileva, 2011).

\subsection{Overconfidence}

Loads of evidence shows that decision makers are by and large overconfident. Overconfidence is commonly closely associated with unwarranted optimism and unlikely wishful thinking which enable investors to overemphasize their talent and the accurateness of the information they own. Excess confidence makes people feel good and moves them to do things they might not otherwise have done and it may lead to decisions that are less than fully rational. Overconfidence is occasionally characterized as a delusion of control and to overstressing what can be anticipated from undeniably "better-than-average" competence and performance (Peterson, 2010). Managers or owners of firms who engage in a variety of investments abroad may behave in an irrational way and their expectations about the future may lead to overconfidence ignoring pertinent information concerning FDI location decisions.

\subsection{Representativeness}

Representativeness is one of the most essential psychological approaches associated with heuristics and biases. It is a perceptual shortcut where the likelihood of an incident or a state is predicted by way of evaluating the degree to which incoming information is comparable with a particular recalled pattern (Tversky \& Kahneman, 1974). 
Representativeness alludes to the tendency of people to draw subjective probability decisions relying on resemblance to stereotypes. Nevertheless, distinguishing the representativeness heuristic is simpler than describing it. Gilovich (1991) elucidates the characteristics of the heuristic as: "Representativeness is a tendency to assess the similarity of outcomes, instances and categories on relatively salient and even superficial features, and then to use these assessments and similarity as a basis of judgment. People assume like goes with like."

\subsection{Anchoring}

Anchoring is a perception bias that occurs when we are trying to make estimation in something about which we have inadequate information. It encompasses adjustment from some initial point. The initial point may refer to current data, for instance, the current rate of inflation or economic growth. Nonetheless, that initial starting point appears to be less familiar to the people who draw that decision.

Kahneman and Tversky (1974) described that when people try to guess a parameter or quantity, they begin their thought procedure by assuming a value that is sometimes entirely random. They progressively deviate from the originally presumed figure at the time they process more information and seek the correct answer. However, there is significant empirical literature which confirms that people turn out to be very extremely involved in the starting value (the "anchor") and cannot modify their last guesses appropriately.

Grinblatt and Keloharju (2001) and Beckmann et.al (2008) identified that a shared language and cultural background became a significant reference point for FDI decision makers to the process of investing overseas. A particular historical practice of each investing firm that determine the concept of mental distance are caused by this cultural and language impact of the two countries.

\subsection{Availability}

Availability bias takes place when people unreasonably remember the noticeable events, i.e. those that are very fresh and/or those that they are or were passionately concerned with, particularly events happened in the recent past. As Schwartz (2010) explained it, people straightforwardly are able to bring to mind the occurrences and information that have freshly occurred, mainly in the media and corporate releases, since their broker's or advisor's suggestions are new in their memory.

This is because they believe that those events might have a superior possibility of occurrences. Therefore, their decision making ability will be influenced by that and they make irrational decision since there is no logical connection between recent happenings and the future ones. Like the decision making in the financial markets, long-term cross boarder decisions making is affected by current, sudden and well broadcasted incidents which is misjudged by investors while the reverse event like familiarity and consistency bring about undervaluation of the importance of events. Hence, this illusion might cause the owners or managers to change FDI location decisions (Alves, 2008). 


\subsection{Prospect theory}

One of the groundbreaking contributions in behavioral finance discipline is the prospect theory, which was contributed by the two psychologists Kahneman and Tversky in 1979. They found empirically that, under conditions of uncertainty, people underestimate outcomes that are purely likely in comparison with outcomes that are acquired with certainty. Their finding is contrary to the expected utility theory which argues that people tend to prefer the option which makes them satisfied. In short, expected utility deals with the way people should act, whereas prospect theory pertains to the manner people definitely act. Under the prospect theory loss aversion, regret aversion and mental accounting are discussed below.

\subsection{Loss aversion}

A more thorough investigation of how people react discloses that they are affected by loss aversion i.e., they sense a greater pain from losses than they obtain an advantage from proportionate gains. In other words, the notion of loss aversion is stand on the foundation that humans assign more significance to losses than they do to gains. Hence, investors' susceptibility and responsiveness become extraordinary when they deal with losses and reductions in their investments than they do in gains and increases.

Consistent with prospect theory, an individual evaluates an alternative of losses and gains corresponding to an appropriate reference point in dollar values connected to loss-averse behavior. According to behavioral economists and researchers, loss aversion and other investors' behaviors are global in nature and all multinational companies' managers share them since they come from diverse countries and cultures (Aharoni, 2011).

\subsubsection{Regret aversion}

People are sensitive when they make decisions that provide them the opportunity to get rid of feeling emotional pain in the occurrence of a disadvantageous outcome. Closing an account at a loss is challenging due to regret aversion. Shefrin and Statman (1985) claim that the panic of causing regret drives an investor to put off losses, though on the opposite side, the desire for self-esteem (delight) initiates the recognition of gains. An investor senses remorseful when closing a position with a loss as a result of the unfortunate investment decision that was undertaken, on the other hand satisfies when achieving a position with a gain since the financial decision bring about a return. As for selfcontrol, it is debated that although investors habitually are familiar with the mistake they are doing, they have trouble controlling the feelings to keep losers.

\subsubsection{Mental accounting}

The other psychological phenomenon is mental accounting, which defines individuals' behavior of splitting up incomes and expenses into distinct accounts that are dealt with in a different way (Thaler, 
1985). People employ this disguised method to code and calculate financial results: transactions, investments, gambles and so on by means of producing diverse "accounts" in their mind for numerous gains or losses. In addition, they associate together explicit groupings of inflows and outflows.

Conventionally, economists have presumed that funds are fungible (interchangeable); however, due to the "silo approach" shaped by mental accounting, people do not treat them as substitutable. Real decisions that people make point out that money is not all the time fungible. Even though some misrepresentations and otherwise abnormal manners can arise, mental accounting can bring favorable results in that it might benefit people exercise self-discipline, enhancing the habit of rules and encourage spending less and saving more money. Similar to investors in financial markets, FDI investors or managers might behave in way that they treat their different investment elements in their investment portfolio separately.

\section{Data and Methodology}

Primary data relevant to the study were collected in the form of survey. Out of around 248 Turkish firms with and without Ethiopian partners under pre-implementation, implementation and operation status, a sample of 95 Turkish foreign direct investors which are operating and are fully owned by Turkish investors were included in the survey. The survey was filled by the owners of those firms in both English and Turkish version of the questionnaire within three months. Due to the dispersed location of the investors and companies, it was found convenient to take samples from companies and investors working in the capital Addis Ababa and the nearby industrial zones. The questionnaires were distributed through electronic form via social media and email in addition to face to face contacts.

The survey tried to assess existence of some elements of behavioral biases on Turkish FDI investors in Ethiopia. Therefore, the survey questions were organized to check whether there is cognitive illusion in their FDI investment decision making or not.

The questions focused on selected behavioral rules like herding, representativeness, overconfidence, anchoring and availability biases as well as prospect theory variables like loss aversion, regret aversion and mental accounting. A 5-point interval scale that is employed to evaluate respondents judgement and attitudes were used to examine the investors' degree of agreement or disagreement towards the stated behavioral anomalies. In addition, dependent variables namely type of business, size of the company, amount of investment and FDI duration were used to assess their association with and effect on behavioral irregularities.

Factor analysis was chosen to analyze the survey data. It employs mathematical techniques for the simplification of interconnected events to determine trends in a group of variables. Exploratory factor analysis (EFA), which is one of the techniques that tries to reveal multifaceted arrangements by discovering the dataset and testing forecasts, was applied to examine which behavioral variables go together and the number of factors that instigate the variables (Child, 2006). Factor analysis 
is beneficial and practical since it simplifies a large set of variables into smaller sets and thereby concentrating on few and significant factors to ease meaningful explanations.

In order to scrutinize the relationship between the dependent variables stated above and the behavioral factors, Ordinary Least Square (OLS) regression analysis method was used. The data were analyzed using Eviews 8.0 software package.

\section{Analysis and Findings}

\section{I. Descriptive Statistics}

The statistical results of the study based on the sample of 95 Turkish FDI investors are depicted in table 1. It shows that the about one-third that is $74 \%$ of the firms are medium size in terms of amount of capital and number of employees. Textile, hotels and restaurants and agro processing sectors are some of the preferred sectors for investments. Concerning the duration of investment, $68 \%$ of the firms have been operating in Ethiopia from one to five years. 63\% the firms allocated till 20 million USD in the form of capital in their investment in Ethiopia and almost $90 \%$ of them targeted both local and foreign customers in the process of selling products and providing services.

Table I: Responses to General Information about the Firms

\begin{tabular}{|c|c|c|}
\hline Items and responses & No. & Percentage \\
\hline \multicolumn{3}{|l|}{ Type of Business } \\
\hline Textile & 20 & 21 \\
\hline Hotels and restaurants & 20 & 21 \\
\hline Agriculture and agro-processing & 15 & 16 \\
\hline Construction & 10 & 11 \\
\hline \multicolumn{3}{|c|}{ Size of the firm(by number of employees) } \\
\hline Small & 10 & 10.5 \\
\hline Medium & 70 & 73.7 \\
\hline Big & 15 & 15.8 \\
\hline \multicolumn{3}{|l|}{ Duration of investment } \\
\hline $1-5$ years & 65 & 68.4 \\
\hline $6-10$ years & 25 & 26.3 \\
\hline $11-15$ years & 5 & 5.3 \\
\hline 16 years and above & 0 & 0 \\
\hline \multicolumn{3}{|l|}{ Target customer } \\
\hline Local & 5 & 5.3 \\
\hline Foreign & 5 & 5.3 \\
\hline Both & 85 & 89.5 \\
\hline \multicolumn{3}{|l|}{ Amount of Investment (in USD) } \\
\hline $1-20$ million & 60 & 63.2 \\
\hline 21-40 million & 20 & 21.1 \\
\hline $41-60$ million & 5 & 5.3 \\
\hline 61 million and above & 10 & 10.5 \\
\hline
\end{tabular}


Table 2: Descriptive Statistics for Dependent Variables

\begin{tabular}{|c|c|c|c|c|c|c|c|c|}
\hline Variables & $\mathrm{N}$ & Min. & Max. & Mean & Std. Dev. & Variance & Skew & Kurtosis \\
\hline Size & 95 & & & & & & & \\
\hline Duration & 95 & 1.00 & 3.00 & 2.052 & 0.5129 & 0.263 & 0.087 & 0.891 \\
\hline Target & 05 & 1.00 & 3.00 & 1.368 & 0.5844 & 0.342 & 1.348 & 0.849 \\
\hline Amount & 95 & 1.00 & 3.00 & 2.842 & 0.4906 & 0.241 & -3.119 & 8.667 \\
\hline $\begin{array}{l}\text { Valid N } \\
\text { (listwise) }\end{array}$ & 95 & 1.00 & 4.00 & 1.631 & 0.9898 & 0.980 & 1.474 & 0.942 \\
\hline
\end{tabular}

Herding (choice of sector), anchoring and loss aversion responses have significant positive, negative and negative correlations respectively with size of the investing firms at 5\% level. Herding (choice of sector, amount of investment and buying and selling decisions) variables have positive significant correlation with duration of investment at $5 \%$ level whereas overconfidence has positive but speed of herding, representativeness and loss aversion have negative significant correlation with duration at $10 \%$ level. Finally, overconfidence and loss aversion found to have positive and significant correlation with amount of investment at $5 \%$ level.

Table 3: Descriptive Statistics for Dependent Variables

\begin{tabular}{|l|l|l|}
\hline Selected behavioral variables & Mean & Std. Deviation \\
\hline Herding - choice of sector & 3.21 & 1.701 \\
Herding - amount of investment & 2.74 & 1.649 \\
Herding - buying and selling & 2.94 & 1.543 \\
Herding - speed of herding & 2.58 & 1.437 \\
Overconfidence & 3.74 & 1.548 \\
Anchoring & 3.15 & 1.403 \\
Anchoring & 3.73 & 1.476 \\
Anchoring & 4.06 & 1.033 \\
Representativeness & 3.93 & 1.241 \\
Loss aversion & 3.13 & 1.390 \\
Loss aversion & 2.40 & 1.385 \\
Regret aversion & 2.84 & 1.489 \\
Risk aversion & 3.14 & 1.589 \\
Mental accounting & 3.45 & 1.373 \\
\hline Valid N (listwise) & & \\
\hline
\end{tabular}

Table 2 and 3 illustrate the overall descriptive statistics of both dependent variables and behavioral factors respectively. Anchoring and representativeness biases have the highest mean scores followed by overconfidence, mental accounting and herding (choice of sector) variables. The lowest mean scores have been registered for loss aversion, herding (speed of herding and amount of investment) 
Table 4: Correlation Analysis Between Firm Information and Behavioral Factors

\begin{tabular}{|l|l|l|l|l|}
\hline Variables & Size & Duration & Target & Amount \\
\hline Size & 1 & & & \\
Duration & -0.243 & & & \\
Target & -0.178 & -0.537 & 1 & 1 \\
Amount & 0.143 & 0.053 & 0.098 & 0.046 \\
Gender & 0.035 & 0.217 & -0.111 & -0.048 \\
Herding - choice of sector & $0.290^{* *}$ & $0.347^{* *}$ & $-0.340^{* *}$ & -0.092 \\
Herding - amount of investment & -0.046 & $0.430^{* *}$ & $-0.248^{*}$ & 0.022 \\
Herding - buying and selling & -0.064 & $0.375^{* *}$ & $-0.221^{* *}$ & -0.097 \\
Herding - speed of herding & 0.027 & $-0.218^{*}$ & 0.068 & $0.405^{* *}$ \\
Overconfidence & 0.087 & $0.245^{*}$ & -0.135 & -0.199 \\
Anchoring & $-0.300^{* *}$ & 0.017 & 0.101 & 0.172 \\
Anchoring & -0.117 & 0.134 & -0.141 & 0.139 \\
Anchoring & 0.091 & 0.126 & -0.027 & 0.019 \\
Representativeness & -0.103 & $-0.204^{*}$ & -0.086 & $0.312^{* *}$ \\
Loss aversion & -0.012 & $-0.203^{*}$ & 0.037 & 0.036 \\
Loss aversion & $-0.328^{* *}$ & 0.069 & 0.098 & 0.175 \\
Regret aversion & -0.127 & 0.127 & 0.110 & -0.271 \\
Risk aversion & 0.117 & -0.192 & 0.020 & -0.031 \\
Mental accounting & 0.121 & -0.064 & -0.036 & \\
\hline Con & & & \\
\hline
\end{tabular}

* Correlation is significant at the 0.05 level (2-tailed)

* Correlation is significant at the 0.05 level (2-tailed)

Table 5: KMO and Bartlett's Test Results

\begin{tabular}{|l|l|l|}
\hline \multicolumn{2}{|l|}{ Kaiser-Meyer-Olkin Measure of Sampling Adequacy } & .625 \\
\hline \multirow{3}{*}{ Bartlett's Test of Sphericity } & Approx. Chi-Square & 690.67 \\
& df & 36 \\
& Sig. & .000 \\
\hline
\end{tabular}

\subsection{Factor Analysis}

A factor analysis relying on 14 behavioral items were made in order to determine essential measurements of the items, which are supposed to be significant, by the survey respondents. The Bartlett test of Sphericity $(\rho<0.000)$ and the Kaiser-Meyer-Olkin (KMO) measure of sampling adequacy (with a value of 0.625 ) validates the suitability of the data for exploratory factor analysis 
Table 6: Correlation Analysis Between Firm Information and Behavioral Factors

\begin{tabular}{|l|l|l|l|l|l|l|}
\hline No & Variable name & Communality & Factor & Eigen value & $\begin{array}{l}\text { Percent of } \\
\text { variance }\end{array}$ & $\begin{array}{l}\text { Cumulative } \\
\text { percent }\end{array}$ \\
\hline $\mathbf{1}$ & Anchoring & 0.938 & 1 & 3.787 & 42.073 & 42.073 \\
$\mathbf{2}$ & Representativeness & 0.726 & 2 & 2.414 & 26.825 & 68.897 \\
$\mathbf{3}$ & Herding (choice of sector) & 0.860 & 3 & 1.095 & 12.168 & 81.066 \\
$\mathbf{4}$ & Herding (amount of investment) & 0.894 & & & & \\
$\mathbf{5}$ & Regret aversion & 0.759 & & & & \\
$\mathbf{6}$ & Herding (buying and selling decisions) & 0.861 & & & & \\
$\mathbf{7}$ & Overconfidence & 0.866 & & & & \\
$\mathbf{8}$ & Anchoring & 0.605 & & & & \\
$\mathbf{9}$ & Mental accounting & 0.787 & & & & \\
\hline
\end{tabular}

Principal component analysis was chosen to decrease the number of factors with an eigenvalue greater than 1 provided that our intention was to categorize the minimum number of factors that would constitute the maximum share of variance of the original items. The primary condition in identifying the number of factors which are appropriate is to select a cumulative percentage of variance greater than $50 \%$. Hence, in table 6 , a cumulative percentage of nearly $81.17 \%$ comprising the first three variables out of 9 original behavioral variables have been identified.

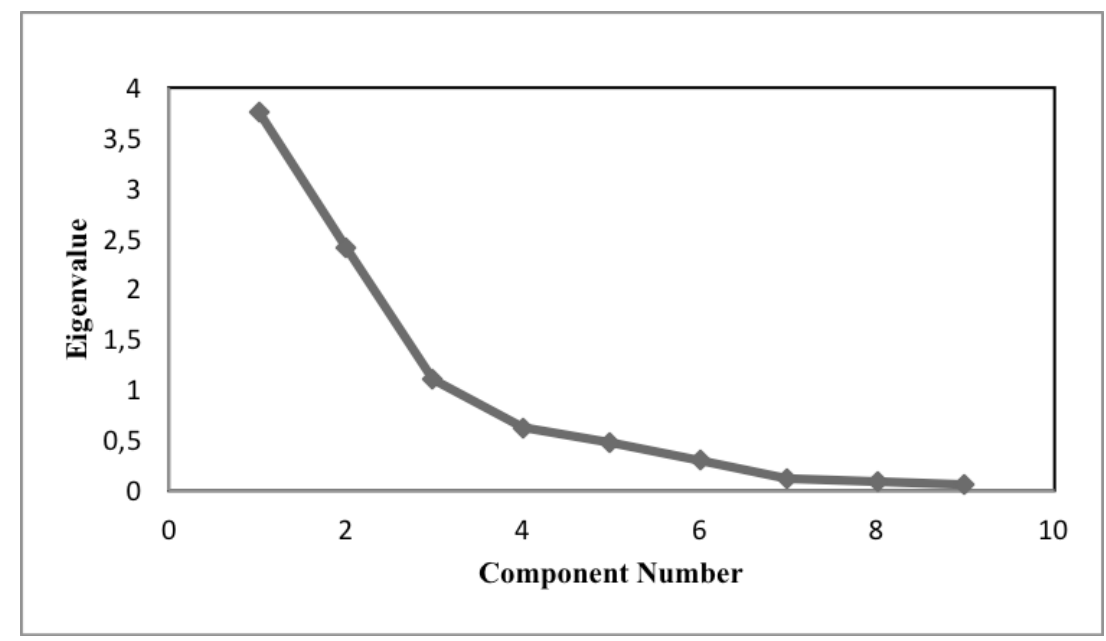

Figure I: The Scree Plot

The scree test (see Figure 1) displays eigenvalues and factors. The number of factors to be considered is the data points that are above the breakdown point (i.e., point of inflexion). There are a limited number of factors which are gauged more accurately than the other remaining factors. Therefore, the above graph based on the eigenvalues shows that the first three prevailing values fall above the straight line whereas the rest fall below the line. 
Table 7: Rotated Component Matrix based on Varimax with Kaiser Normalization Method

\begin{tabular}{|l|l|l|l|}
\hline \multirow{2}{*}{ Variable name } & Factor & $\mathbf{2}$ & $\mathbf{3}$ \\
\cline { 2 - 3 } & $\mathbf{1}$ & & \\
\hline Anchoring & 0.945 & 0.927 & \\
Representativeness & 0.900 & 0.910 & \\
Herding (choice of sector) & 0.729 & 0.846 & \\
\cline { 2 - 3 } Herding (amount of investment) & 0.726 & & 0.830 \\
Regret aversion & & & 0.805 \\
Herding (buying and selling decisions) & & & \\
Overconfidence & & & \\
Anchoring & & & \\
Mental accounting & & & \\
\hline
\end{tabular}

The first factor includes anchoring, representativeness and herding (choice of sector and amount of investment). The second factor consists of loss aversion, herding (buying and selling decisions) and overconfidence whereas the third factor comprises anchoring and mental accounting.

Having illustrated that the study had demonstrated a stable solution, analysis of the varimax-rotated factor loading was implemented (see table 7). After disregarding the negative loadings, the final positive loadings have been shown on factors 1, 2 and 3. Consequently, the study identified three factors, which constitute the behavioral biases of Turkish FDI investors in Ethiopia while making investment decisions.

\subsection{Reliability and Consistency Test}

Cronbach's Alpha Test is employed to check the reliability of internal consistency of measurements in which the entire items measure identical concept or construct and therefore it is linked with interconnectedness of the items within the test (Tavakol \& Dennick, 2011). It takes account of a statistical summary that defines the steadiness of a particular sample of respondents across a number of questions or variables. It enables us to predict the dependability of participants' responses to the respective measurements. Cronbach's alpha is commonly applied in social and behavioral researches as a gauge of reliability of a study.

Table 8: Reliability and Internal Consistency Results

\begin{tabular}{|l|l|l|}
\hline Factors and variables & Item-total correlation & $\boldsymbol{\alpha}$ value \\
\hline Factor 1 & 0.017 & 0.782 \\
\hline Representativeness & 0.529 & 0.656 \\
Herding(choice of sector) & 0.658 & 0.610 \\
\hline Herding (amount of investment) & 0.542 & 0.653 \\
\hline Factor 2 & 0.651 & 0.617 \\
\hline Regret aversion & 0.324 & 0.716 \\
Herding (buying and selling decisions) & \multicolumn{2}{|l|}{} \\
\hline Factor 3
\end{tabular}


The reliability and consistency test is demonstrated in table 8 . As a general rule, values closer to one imply a greater internal consistency whereas values closer to zero show an inferior internal consistency. According to the statistical result, the overall Cronbach's alpha value is $71 \%$, which is considered acceptable in some studies (McMillan \& Schumacher, 2001) (Blunch, 2008) even though some other studies confirm that it is tolerable to have alpha values above $60 \%$. Therefore, it safe to infer the reliability and internal consistency of this study is satisfactory and suitable to apply regression test. Due to inconsistency, from the first and third factors anchoring and from the second factor overconfidence variables were disregarded from study. Hence, the main behavioral anomalies of Turkish FDI investors in Ethiopia are representativeness; herding variables (choice of sector, amount of investment and buying and selling decisions), regret aversion and mental accounting.

Table 9: Regression Test Results

\begin{tabular}{|l|l|l|l|l|}
\hline Variables & Size & Duration & Target & Amount \\
\hline Herding choice & $0.250^{*}$ & 0.057 & $-0.096^{* *}$ & $0.174^{* *}$ \\
Herding amount & $-0.220^{*}$ & $0.123^{* * *}$ & 0.059 & $-0.218^{* * *}$ \\
Herding buying & 0.034 & 0.012 & $-0.131^{* * *}$ & -0.026 \\
Representativeness & 0.056 & $0.216^{*}$ & -0.086 & $0.301^{*}$ \\
Regret aversion & 0.061 & 0.044 & $0.124^{*}$ & $0.352^{*}$ \\
Mental accounting & 0.037 & $-0.221^{*}$ & -0.007 & $-0.517^{*}$ \\
\hline
\end{tabular}

${ }^{*}$ Denote significance at $1 \%$ levels

** Denote significance at $5 \%$ levels

${ }^{* * *}$ Denote significance at $10 \%$ levels

\subsection{Regression Analysis}

Having examined rotated principal component loadings, scree test, KMO and Bartlett's test, and a reliability test based on the survey data which focused on the behavioral biases of Turkish FDI investors in Ethiopia, in table 9, the regression analysis was demonstrated. The result indicated the association between Turkish FDI firms' general information (size, duration, target and amount of investment) and behavioral variables stated earlier. The table depicts the value of coefficients and their respective significance level. Though various studies used $1 \%, 5 \%$ and $10 \%$ level of significances together, this study employed 5\% level of significance as a cut-off point to forecast or predict the relation between the variables.

Accordingly, size and amount of investment have positive while target has negative relationship with herding (choice of investment). It shows that when FDI investors' firm size and investment amount increases, the owners tend to follow the herd exceedingly whereas when their target encompasses the global market, they abandon to follow the herd. Herding (amount of investment) negatively affected by size i.e. when firms size increases, following the herd (by the amount of investment) weakens. 
Representativeness has a positive and significant link with duration and amount of investment, that is, when the investing firms stay for a long time in the host country and invest more money; they have a tendency to forecast the changes in their future investment based on the recent performance which is one of indicators of representativeness heuristic.

Regret aversion found to have positive and significant association with target of customers and amount of investment variables. The way investors try to address both local and foreign customers and greater investment amount results in avoiding selling properties/business ventures that have decreased in value and readily sells those that have increased in value which is a typical form of loss aversion behavior. Finally, duration and amount of investment have positive and significant relation with mental accounting. It implies that when firms stay for long and invest a significant amount of money, they tend to treat each element/account in their investment portfolio separately that is one type of mental accounting, which is psychological phenomenon of splitting up incomes and expenses into distinct accounts that are dealt with in a different way.

\section{Conclusion}

In this paper an attempt has been made to study the major behavioral biases of Turkish FDI investors in Ethiopia with regard to their long-term decision making in different sectors of the country's economy. Moreover, the relationship between the investors firms' general information namely size, duration, target customers and amount of investment and the behavioral anomalies has been analyzed. A survey was conducted covering a list of questions to assess the existence of behavioral anomalies on Turkish FDI investors in Ethiopia. The results of factor analysis confirm that psychological irregularities such as representativeness, herding, regret aversion and mental accounting have been observed on Turkish FDI in investors while they are making investment decisions in Ethiopia. This finding refutes partly the traditional economic view which is based on rational decision making of investors. In addition, the findings based on the regression analysis, though mixed, supports that amount of investment of the firm positively affects herding, representativeness, regret aversion and mental accounting. This implies that when the FDI investors put more money in their investment, their emotional and psychological abnormality rise and lead them to make irrational economic decisions. In addition, duration of investors in Ethiopia affects their representativeness and mental accounting behavioral biases positively. It can be inferred that the longer Turkish FDI investors stay in Ethiopia, the higher they apply cognitive psychological biases in their economic and financial decisions.

Therefore, policy analysts, decision makers, and researchers in this area should benefit from such findings and consider behavioral factors of FDI in addition to economic, political and social factors and give due consideration in their policy analysis and academic papers. Potential researchers can study behavioral biases of other FDI investors in Ethiopia and compare with Turkish investors employing the same or different behavioral variables, which help them get the full picture as to how investors are attracted to FDI. 


\section{References}

Ackert, L., \& Deaves, R. (2010). Behavioral Finance Psychology, Decision-Making, and Markets (1 ed.). Mason: South-Western Cengage Learning.

Aharoni, Y. (2011). Behavioral elements in foreign direct investments. Research in Global Strategic Management, 15(15), 23-60.

Alves, R. P. (2008). Behavioural Determinants of Foreign Direct Investment. Lisbon: Gabinete de Estratégia e Estudos, Ministério da Economia.

Amanuel, M. (2015). Factors affecting FDI flow in Ethiopia: An empirical investigation. International Journal of Current Research, 7(2), 12608-12614.

Araujo, S. (2009). Imitative behaviour and FDI location choice: An empirical assessment. IFN Seminar. Stockholm: Research Institute of Industrial Economics.

Atlaw, D., Teklemariam, D., \& Dong-Geun, H. (2014). Determinants of foreign direct investment: Reflections from Ethiopia. Social and Basic Sciences Research Review, 2(2), 85-95.

Baker, K., \& Nofsinger, J. (2010). Behavioral Finance: An Overview. In K. Baker, \& J. Nofsinger (Eds.), Behavioral Finance: Investors, Corporations, and Markets (pp. 03-22). New Jersey: John Wiley \& Sons, Inc.

Barberis, N., \& Thaler, R. (2003). A survey of behavioral finance. In G. Constantinides, M. Harris, \& R. Stulz (Eds.), Handbook of the Economics of Finance (pp. 1051-1121). North Holland: Elsevier Science B.V. .

Beckmann, D., Menkhoff, L., \& Megumi, S. (2008). Does culture affect asset managers' views and behavior? Journal of Economic Behavior \& Organization, 67(3-4), 624-643.

Blunch, N. J. (2008). Introduction to structural equation modelling using SPSS and AMOS. . Thousand Oaks CA: Sage Publications LtD.

Burton, E., \& Shah, S. (2013). Behavioral finance: Understanding the social, cognitive, and economic debates. New Jersey: John Wiley \& Sons, inc.

Child, D. (2006). The essentials of factor analysis (3rd ed.). New York: Continuum International Publishing Group.

Eiteman, D., Stonehill, A., \& Moffett, M. (2013). Multinational business finance (13 ed.). New Jersey: Pearson Education, Inc.

Fama, E. (1998). Market Efficiency, Long-term returns, and behavioral finance. Journal of Financial Economics, 49(3), $283-306$.

Getinet, H., \& Hirut, A. (2006). Determinants of foreign direct investment in Ethiopia: A time series analysis. The 4th International Conference on the Ethiopian Economy. Addis Ababa.

Gilovich, T. (1991). How we know what isn't so: The fallibility of human reason in everyday. New York: The Free Press.

Grinblatt, M., \& Keloharju, M. (2001). What makes investors trade? The Journal of Finance, 56(2), 589-616.

Hosseini, H. (2005). An economic theory of FDI: A behavioral economics and historical approach. The Journal of Socio-Economics, 34, 528-541.

Hutzschenreuter, T., \& et.al. (2014). Corporate strategic responses to foreign entry: Insights from prospect theory. The Mulitnational Business Review, 22(3), 294-323.

Knickerbocker, F. (1973). Oligopolistic reaction and multinational enterprise. Cambridge: Harvard University.

Kuo, C.-L., \& Fang, W.-C. (2009). Psychic Distance and FDI Location Choice:Empirical Examination of Taiwanese Firms in China. Asia Pacific Management Review, 14(1), 85-106.

Levis.M, Muradoglu, G., \& Vasileva, K. (2010). Herding in FDI outlows. International Conference on Computational and Financial Econometrics. London: Senate House. 
McMillan, J. H., \& Schumacher, S. (2001). Research in education: A conceptual introduction. New York: Logman.

Peterson, R. (2010). Neuroeconomics and Neurofinance. In K. Baker, \& J. Nofsinger, Behavioral finance : investors, corporations, and markets (pp. 73-94). New Jersey: John Wiley \& Sons, Inc.

Ritter, J. (2003). Behavioral finance. Pacific-Basin Finance Journal, 11(4), 429-437.

Rosenboima, M., Luskib, I., \& Shavit, T. (2008). Behavioral Approaches to Optimal FDI Incentives. Managerial and Decision Economics, 29, 601-607.

Scharfstein, D., \& Stein, J. (1990). Herd Behavior and investment. The American Economic Review, 80(3), 465479.

Schwartz, H. (2010). Heuristics or Rules of Thumb. In H. K. Baker, Behavioral Finance - Investors, Corporations, and Markets (pp. 57-72). Hoboken, NJ: John Wiley \& Sons, Inc.

Shefrin, H., \& Statman, M. (1985). The Disposition to Sell Winners Too Early and Ride Losers Too Long: Theory and Evidence. Journal of Finance,, 40(3), 777-790.

Shiller, R. (2003). From efficient markets theory to behavioral finance. Journal of Economic Perspectives, 17(1), 83-104.

Shleifer, A., \& Summers, L. (1990). The noise trader approach to finance. Journal of Economic Perspectives, 4, 19-33.

Statman, M. (2008). Countries and culture in behavioral finance. In CFA Institute Conference Proceedings Quarterly, 25(3), 38-44

Tavakol, M., \& Dennick, R. (2011). Making sense of Cronbach's alpha. International Journal of Medical Education, 2, 53-55.

Thaler, R. (1985). Mental accounting and consumer choice. Marketing Science, 4(3), 199-214.

Tversky, A., \& Kahneman, D. (1974). Judgment under uncertainty: Heuristics and biases. Science, 85, 11241131.

Vasileva, K. (2011). Foreign direct investment - a behavioural finance approach. Retrieved June 13, 2017, from City University: http://openaccess.city.ac.uk/1185/ 